\title{
Cantilever failure investigations for cohesive riverbanks
}

1 Supapap Patsinghasanee BEng, MEng PhD Candidate, Graduate School of Engineering, Hokkaido University, Sapporo, Japan (corresponding author: supapap@eis.hokudai.ac.jp)

2 Ichiro Kimura BEng, MEng, PhD Associate Professor, Graduate School of Engineering, Hokkaido University, Sapporo, Japan
3 Yasuyuki Shimizu BEng, MEng, PhD

Professor, Graduate School of Engineering, Hokkaido University, Sapporo, Japan

4 Mohamed Nabi BSc, MSc, PhD Senior Researcher, Deltares, Delft, The Netherlands
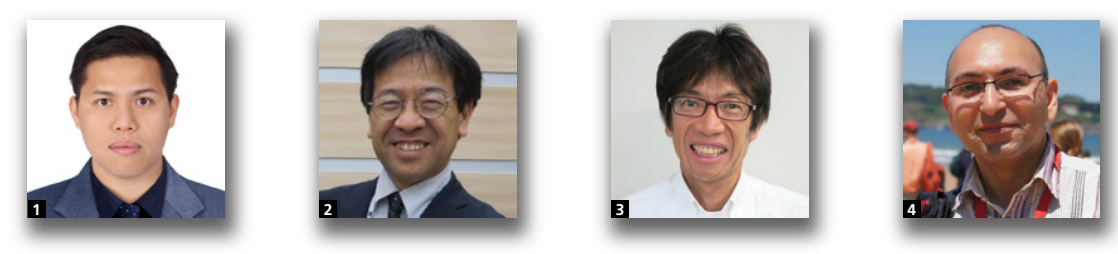

As a cantilever failure involves rapid channel widening and delivers a large volume of sediment into the channel, it is important to understand this mechanism from the river engineering point of view. Different types of riverbank failures have been investigated in several previous studies, but these works have limitations in understanding the complex mechanisms of cantilever failure regarding the coupling of fluvial erosion with that failure. Experiments were thus carried out to assess the underlying mechanisms of cantilever failure using three types of cohesive materials classified on the basis of their percentages of silt-clay content. The experiments showed that fluvial erosion of the lower part of cohesive riverbanks progressively undermines the upper part during the initial stage of a cantilever failure. Tension cracks then develop at the upper surface of the cohesive riverbanks and beam failure occurs thereafter. A mathematical model of cantilever failure was also developed. The model uses a triple-grid approach to simulate the behaviour of a cantilever within the framework of fluvial erosion and the cantilever's subsequent failure. The simulated results show good agreement with the experimental results in terms of spatial-averaged bank width and water level along cohesive riverbanks.

\section{Notation}

$A_{j} \quad$ cross-sectional area in each calculated cell

$b \quad$ overhanging block width

C compressive strength per unit length

$C_{*} \quad$ ratio of equilibrium concentration of suspended sediment

$C_{\mathrm{L}} \quad$ coefficient of lift force near the riverbank surface

$C_{\mathrm{L}}^{\prime} \quad$ coefficient of lift force

CW width of a calculated cell of the cohesive riverbank

$C_{\mathrm{z}} \quad$ compressive zone length

$c_{\mathrm{c}} \quad$ Chezy's roughness coefficient

D water depth

$d_{50} \quad$ mean diameter

E erosion coefficient

e

$\mathrm{FE}$

FD

FR

Fr coefficient to reflect the effect of a bank failure simulated fluvial erosion in each timestep driving forces acting on the overhanging failure block

resisting forces acting on the overhanging failure block

Froude number
$F_{\text {sb }}$

$F_{\text {ss }}$

g

$H_{\mathrm{O}}$

$H^{\prime}$

$i$

$j$

$k_{\mathrm{s}}$

$M_{\mathrm{e}}$

$n$

$P_{j}$

$q_{\mathrm{bn}}$

$q_{\mathrm{bs}}$

$R^{2}$

$\operatorname{Re}$

$R_{j}$

SC safety factor of beam failure

safety factor of shear failure gravity acceleration

initial bank height

overhanging block height

bed slope

lateral calculated cell number

relative roughness height

rotational moment resulting from the weight of the overhanging block

rate of bank erosion

Manning roughness parameter

perimeter length in each calculated cell

sediment transport rate in lateral direction

sediment transport rate in streamwise direction

correlation coefficient

Reynolds number

hydraulic radius in each calculated cell

percentage of silt-clay content

specific weight of sediment

tensile strength per unit length 


$\begin{array}{ll}T_{\mathrm{z}} & \text { tensile zone length } \\ t & \text { time } \\ u^{*} & \text { shear velocity } \\ u_{j} & \text { velocity in each calculated cell } \\ W & \text { overhanging block weight } \\ y & \text { coordinate component in lateral axis } \\ Z_{\mathrm{b}} & \text { bed elevation in calculated cell } \\ z_{\mathrm{c}} & \text { maximum depth of tension crack } \\ \bar{\beta} & \text { average cohesive riverbank angle } \\ \gamma & \text { unit weight of soil } \\ \theta & \text { angle of repose } \\ \kappa & \text { von Kármán constant } \\ \lambda & \text { porosity of the material } \\ \mu_{\mathrm{k}} & \text { kinetic friction coefficient } \\ \mu_{\mathrm{s}} & \text { static friction coefficient } \\ \bar{\xi} & \text { depth-averaged bank erosion rate from fluvial } \\ & \text { erosion } \\ \rho & \text { density of water } \\ \rho_{\mathrm{s}} & \text { density of sediment particles } \\ \tau_{*} & \text { non-dimensional bed shear stress } \\ \tau_{* \mathrm{c}} & \text { non-dimensional critical bed shear stress } \\ \tau_{\mathrm{bo}} & \text { actual shear stress } \\ \tau_{\mathrm{bc}} & \text { critical shear stress } \\ \phi & \text { internal friction angle } \\ \Omega & \text { undisturbed cell occupation rate } \\ & \end{array}$

\section{Introduction}

Riverbank failure results in extensive sediment production in an alluvial channel and can cause severe environmental and economic problems such as loss of fertilisation in agricultural areas and destruction of infrastructure (Taghavi et al., 2010). However, because a cantilever failure involves a rapid channel widening and delivers a large volume of sediment into the channel, such a failure is a serious issue in river engineering (Dapporto et al., 2003; Nardi et al., 2012; Taghavi et al., 2010). Elucidating the underlying mechanism of cantilever failure is therefore important for a complete understanding of fluvial erosion and riverbank failure along a channel.

In previous studies, researchers have been unable to analyse cantilever failure and have focused mainly on simple bank failures such as rotational slip failure, toppling failure and mass wasting failure (ASCE, 1998; Duan, 2005; Osman and Thorne, 1988). Moreover, estimations of the failure plane angle and tension crack depth have been analysed using a combination of field and experimental data (Taghavi et al., 2010). Only a few studies have applied stability analyses based on the safety factor of the portion with cantilever failure, from which three types of possible cantilever failure mechanisms - shear, beam and tensile failures - have been defined (Abam, 1997; Thorne and Tovey, 1981).

Several previous studies have reported small-scale cantilever failure experiments, including experimental studies examining fluvial erosion and cantilever bank mechanisms (Fukuoka et al., 1999) and experimental studies measuring flow characteristics near and inside eroded banks (Bahar and Fukuoka, 2002). A couple of large-scale experimental studies on the failure mechanism of cantilevers have been reported recently. Taghavi et al. (2010) conducted experiments to estimate the failure plane angle and tension crack depth, and Samadi et al. (2013) carried out experimental studies to investigate dominant cantilever failure mechanisms, finding that beam and tensile failures are dominant. Moreover, Nardi et al. (2012) conducted experiments to investigate mass failures in a sandy gravel riverbank and showed the occurrence of a variety of failure processes such as cantilever, slab and slide failures. However, all of the large-scale experiments focused solely on processes related to cantilever failure and the interaction between stagnant water and cohesive materials; fluvial erosion was not taken into account.

Previous numerical works have studied simple bank failure mechanisms by using simple bank failure models (ASCE, 1998; Iwasaki et al., 2012; Jang and Shimizu, 2005; Nagata et al., 2000). In addition, a coupled model of fluvial erosion and mass wasting was developed to reproduce fluvial erosion processes in a bank toe, degradation in a channel bed and destabilisation of an upper bank (Darby et al., 2007; Duan and Julien, 2010).

Several numerical methods have been developed towards an understanding of the complex mechanisms of cantilever failure. For example, Bahar and Fukuoka (2002) employed a semi-implicit method, applying a pressure-linked equation algorithm to reproduce flow characteristics near and inside eroded banks. In addition, shear and beam failure mechanisms were studied to identify the significant effects of uncertainty parameters on the reliability of a bank stability model in determining a cantilever failure. The results showed that the overhanging block dimensions and the cohesive force are highly significant for an analysis of cantilever stability (Samadi et al., 2011). A stress-strain behaviour model for a cantilever failure was also applied to simulate the subsequent failure of an overhanging block (Samadi et al., 2013). However, these previous studies have limitations in coupling fluvial erosion with cantilever failure and simulations coupling fluvial erosion and cantilever failure therefore need to be conducted.

To address the gap between experiments and numerical modelling of the process of a cantilever failure, experimental studies were conducted on a rectangular flume in this work. Furthermore, a novel coupled numerical model was developed by considering the effects of fluvial erosion and intermittent cantilever failure for cohesive riverbanks.

\section{Methodology}

This section provides an overview of the experimental setup and a description of the numerical model. 
Cantilever failure investigations for

cohesive riverbanks

Patsinghasanee, Kimura, Shimizu and Nabi

\subsection{Experimental setup}

To address many of the ambiguities in the underlying mechanisms of a cantilever failure and because of a lack of reported experimental studies, laboratory experiments related to fluvial erosion and cantilever failure were conducted using a fixed bed in a straight rectangular channel with Plexiglas walls to allow for real-time observation and recording. The water and sediments were recirculated using a constant-head tank of water placed at the upstream end of a flume, and both sides of the flume had a constant-head tank. Moreover, to reproduce a steady uniform flow for each case examined, the water discharge remained constant at $2 \cdot 4-6 \cdot 41 / \mathrm{s}$ using a notch weir to regulate a constant discharge during the experiments. The initial water level was set to zero and a free-flowing condition was controlled at the downstream end. The flume was $30 \mathrm{~cm}$ wide, $10 \mathrm{~m}$ long and $20 \mathrm{~cm}$ high and the channel slope was set to $1 / 500$, as shown in Figure 1. In the upstream region of the flume (2.0-3.8 $\mathrm{m}$ from the upstream), a wooden board was installed to avoid fluvial erosion (I to II). At the middle reach of the flume $(3 \cdot 8-5 \cdot 2 \mathrm{~m}$ from the upstream), a cohesive riverbank was set (II to III). The cohesive riverbank was $16 \mathrm{~cm}$ wide, $1.4 \mathrm{~m}$ long and $15-20 \mathrm{~cm}$ high, with the height varying in each case considered. Downstream of the cohesive riverbank, a second wooden board was installed to protect the cohesive riverbank from fluvial erosion (III to IV).

During the experiments, sediment composed of sand and silt with mean diameters $\left(d_{50}\right)$ of around $0.23 \mathrm{~mm}$ and $28.4 \mu \mathrm{m}$, respectively, was used. The sediment mixture was initially wetted with water to achieve a water content of $17 \cdot 5-48 \cdot 0 \%$ for silt-clay contents (SC) of $10 \%, 20 \%$ and $30 \%$. For this study, two parameters (i.e. the percentage of silt-clay content and water content) were varied in each case, because the cohesive force of cohesive riverbanks is related mainly to the percentage of silt-clay content (Couper, 2003; Dulal and Shimizu, 2010;

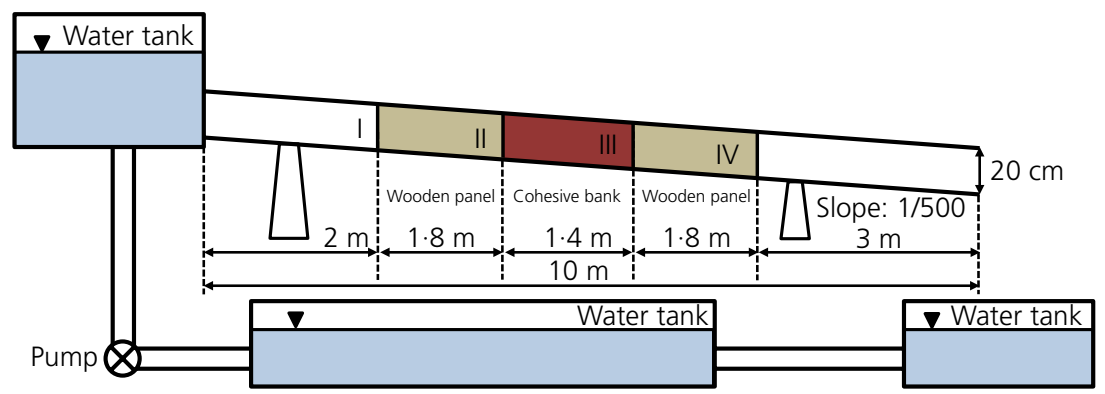

(a)

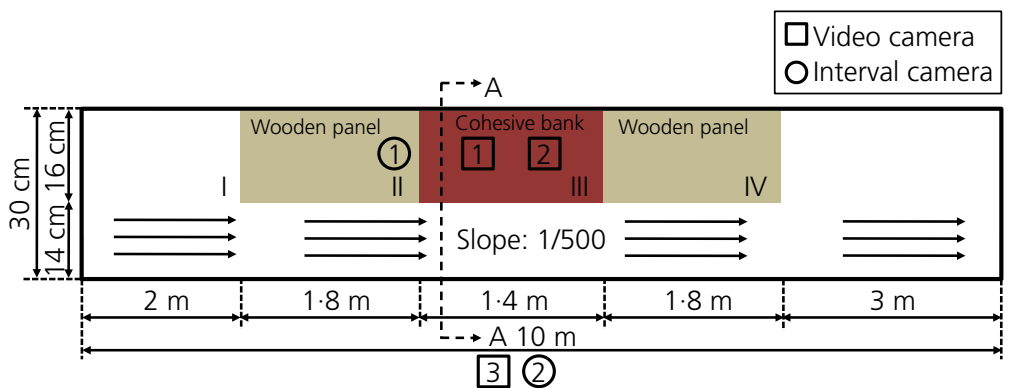

(b)

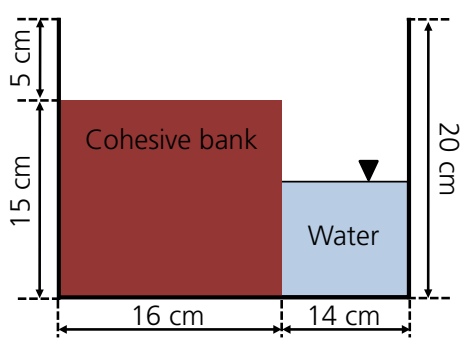

(c)

Figure 1. (a) Overview of experimental setup. (b) Top view of experimental flume. (c) Cross-section (A-A) of experimental flume 
Julian and Torres, 2006) and water content (Couper, 2003; Rinaldi and Nardi, 2013; Thorne and Tovey, 1981). However, the sediment mixtures were prepared by mainly varying the percentage of silt-clay content because, for the sediments used in this study, it was difficult to control the water content with the different percentages of silt-clay content.

Before carrying out the experiments, the cohesive materials were tested to determine the cohesive force and internal friction angle by using a direct shear device based on the ASTM D 3080-98 standard test method for direct shear testing of soil under consolidated drained conditions (ASTM, 1998). Similarly to previous work (Sutarto et al., 2014), the direct shear test used in this study was consolidated by gradually increasing the normal stress by means of ASTM D 2435-96 (ASTM, 1996). The soil samples were carefully trimmed to fit within the shear box dimensions and then placed in the shear box. Moreover, the cohesive materials were consolidated through normal stress under loads of 5,10 and $20 \mathrm{kPa}$ for $24 \mathrm{~h}$. The horizontal and vertical deformations and corresponding applied shear stresses were then recorded simultaneously. The process was conducted for each sample by using the three normal stress loads. The slope of the best-fit line from the data provided the internal friction angle and the $y$-intercept provided the cohesive force (Figure 2). Additionally, a direct shear test of pure sand was conducted to determine the cohesive force $(3.09 \mathrm{kPa})$ and internal friction angle $\left(41 \cdot 28^{\circ}\right)$. However, in this study, a direct shear

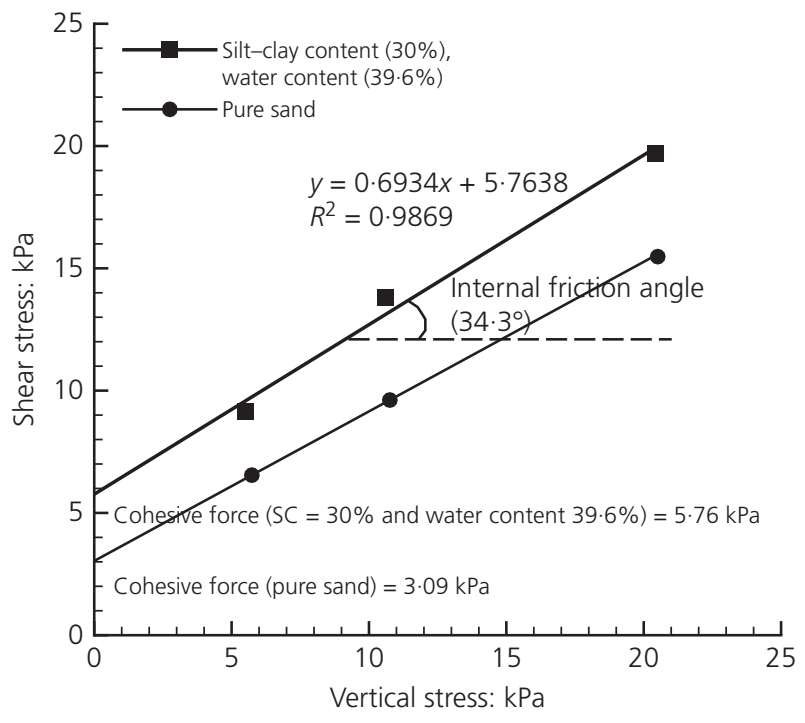

(a)

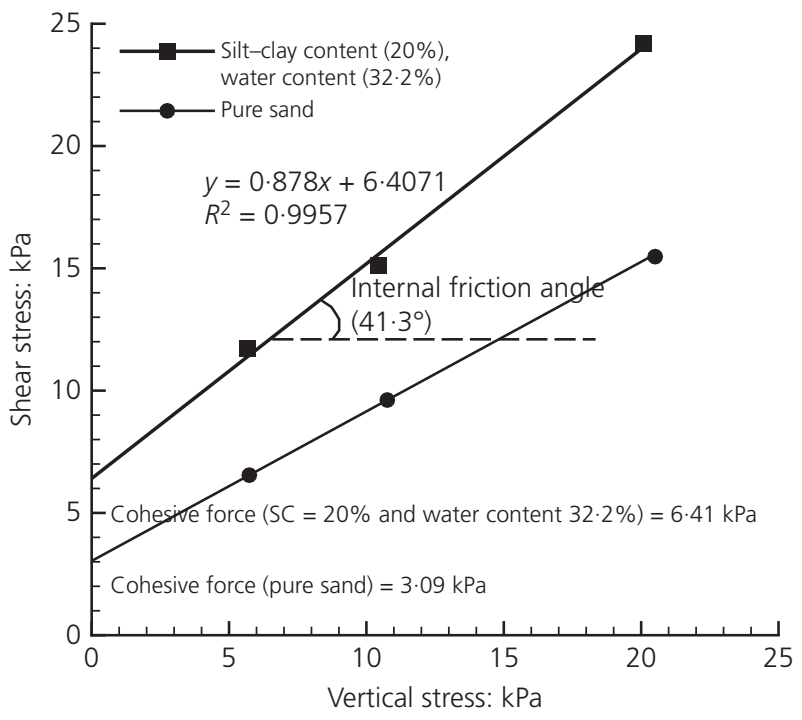

(b)

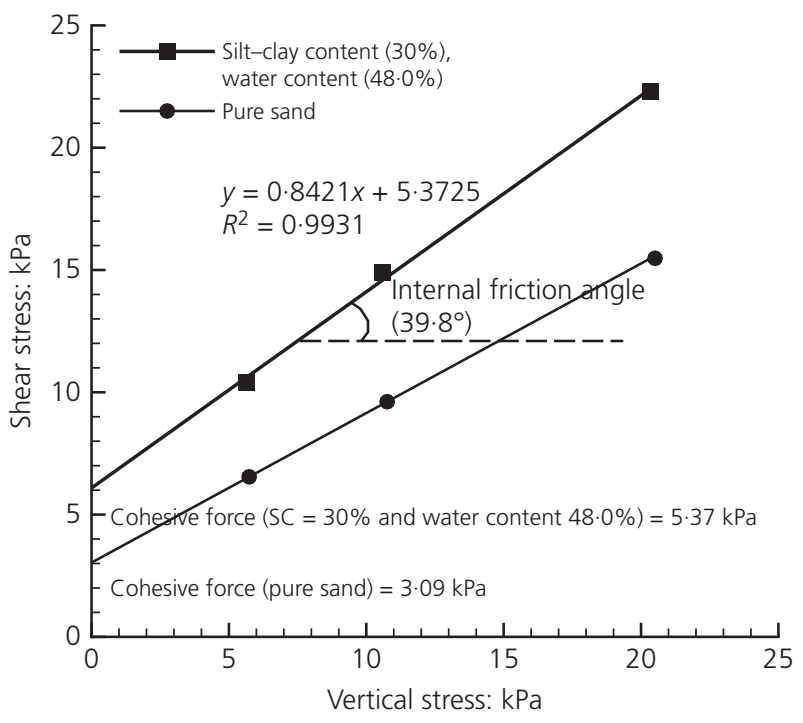

(c)

Figure 2. Direct shear test results of cohesive materials 


\begin{tabular}{|c|c|c|c|c|c|c|c|c|}
\hline Case & $\begin{array}{c}\text { Discharge: } \\
\text { l/s }\end{array}$ & $\begin{array}{c}\text { Bank height: } \\
\text { cm }\end{array}$ & $\begin{array}{c}\text { Silt-clay } \\
\text { content: \% }\end{array}$ & $\begin{array}{c}\text { Water } \\
\text { content: \% }\end{array}$ & $\begin{array}{l}\text { Internal friction } \\
\text { angle: degrees }\end{array}$ & $\begin{array}{l}\text { Cohesive force: } \\
\text { kPa }\end{array}$ & $\operatorname{Re}$ & $\mathrm{Fr}$ \\
\hline 1 & $4 \cdot 0$ & 20 & 10 & $17 \cdot 5$ & N/A & $\mathrm{N} / \mathrm{A}$ & 25000 & 0.78 \\
\hline 2 & $4 \cdot 0$ & 20 & 30 & 39.6 & $34 \cdot 3$ & $5 \cdot 76$ & 25000 & 0.78 \\
\hline 3 & $4 \cdot 0$ & 15 & 30 & $39 \cdot 6$ & $34 \cdot 3$ & $5 \cdot 76$ & 25000 & 0.78 \\
\hline 4 & $2 \cdot 4$ & 15 & 30 & 39.6 & $34 \cdot 3$ & $5 \cdot 76$ & 15000 & 0.74 \\
\hline 5 & $4 \cdot 0$ & 15 & 20 & $32 \cdot 2$ & $41 \cdot 3$ & $6 \cdot 41$ & 25000 & 0.78 \\
\hline 6 & $5 \cdot 8$ & 15 & 20 & $32 \cdot 2$ & $41 \cdot 3$ & $6 \cdot 41$ & 36250 & 0.81 \\
\hline 7 & $6 \cdot 4$ & 15 & 30 & $48 \cdot 0$ & $39 \cdot 8$ & $5 \cdot 37$ & 40000 & 0.82 \\
\hline
\end{tabular}

Table 1. Summary of experimental conditions

test was carried out for only one sample per each normal stress and therefore the results obtained gave a slightly different cohesive force and internal friction angle compared with the replicated sample process (at least three replicates) at each normal stress.

To allow for a sufficient consolidation process, the cohesive banks were compacted by applying a static load of $0.04 \mathrm{~kg} / \mathrm{cm}^{2}$ for $72 \mathrm{~h}$ (Nardi et al., 2012). Dynamic compaction was not used either to protect the Plexiglas walls from damage or to reproduce the natural cohesive riverbank conditions that normally occur through static compaction. During the cohesive riverbank construction, a wooden panel was positioned to form a vertical bank. The panel was removed before the experiments started. The experimental conditions required to stop the test were (1) when cantilever failures proceeded throughout all of the cohesive riverbanks or (2) when an equilibrium stage was reached (without a failure for a $2 \mathrm{~h}$ period). Composite layers were not considered in this study because of uncertainties regarding the cantilever failure phenomenon and lack of previous studies. Each layer had its own geotechnical properties and the overhanging failure block was divided into a number of vertical slices. The bank geometries, discharges and cohesive properties used during the experiments are summarised in Table 1.

The advantage of the experiment was the possibility to observe and record cantilever failure mechanisms from the top and side views of the experimental flume during fluvial erosion, tension cracks and cantilever failure. All failure mechanisms were recorded using three high-resolution video cameras and two interval recorder devices, as shown in Figure 1(b). The video cameras were kept at a fixed perpendicular position for the top and side views of the channel to record the temporal bank width and water depth. Additionally, metric scales were positioned in both the horizontal and vertical directions of the channel. The video frames were subsequently converted into grey-scale metrics and the temporal bank width and water depth were determined through a digitisation process with a precision of around $1 \mathrm{~mm}$.

\subsection{Numerical model}

The main objective of the numerical model was to reproduce the physical mechanisms of fluvial erosion, tension cracks and cantilever failure of the cohesive riverbanks.

A cantilever failure model was developed by implementing a triple-grid approach, consisting of a coarse one-dimensional (1D) grid for the flow field in the lateral direction, a fine 1D grid for sediment transport and bed deformation in the lateral direction and a 2D grid for cantilever failure in the vertical and lateral directions (Figure 3). During the initial stage of the computation (Figure 4), the model reproduced fluvial erosion at the lower part of the riverbank, which is shown by the dashed line in zone 1. Next, the tension crack in zone 2 and the cantilever failure in zone 3 (the dashed vertical line along the cohesive riverbank) were captured using the computational model. This approach involves applying the three submodels fluvial erosion, cantilever failure and bedload sedimentation at each of a series of discrete timesteps. A logic diagram of the computational sequence used for the coupled mechanism of fluvial erosion and cantilever failure is illustrated in Figure 5.

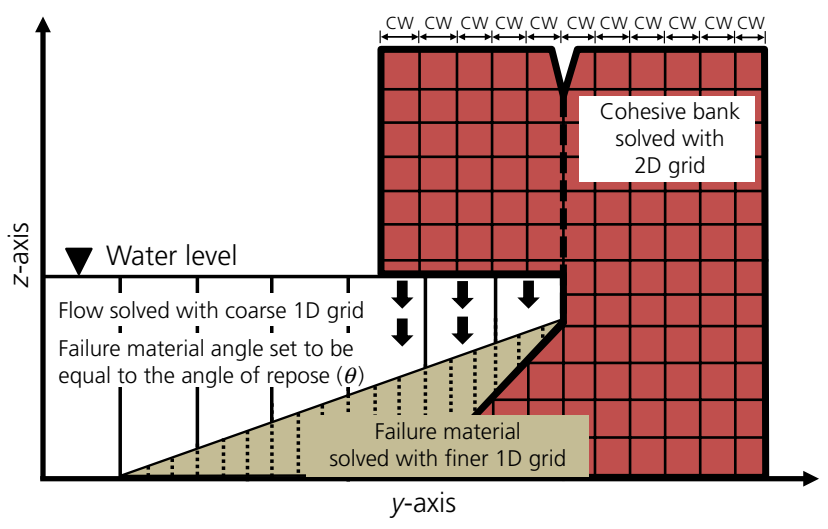

Figure 3. Framework of triple-grid approach of cantilever failure model 


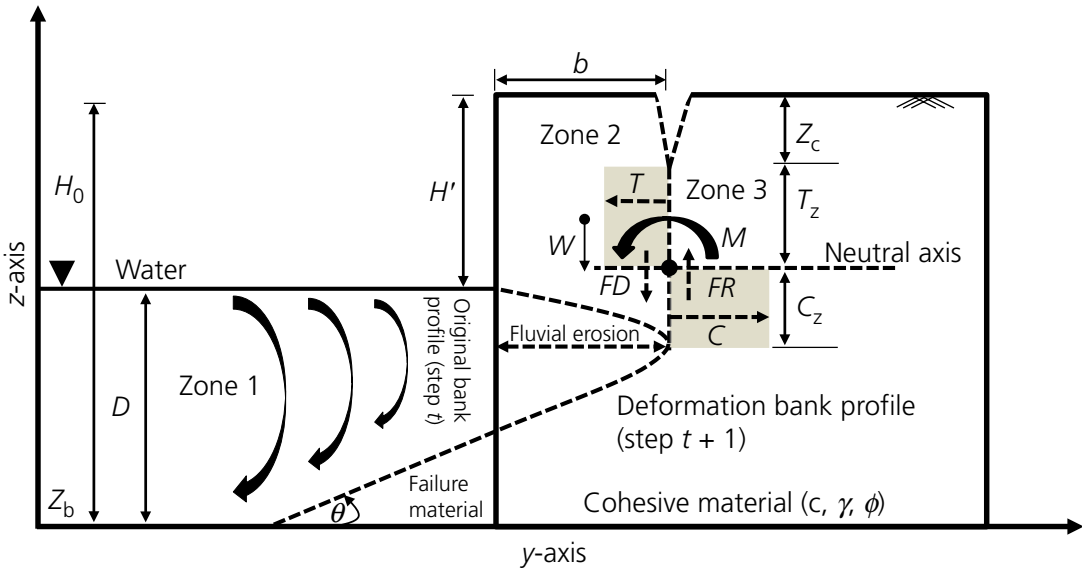

Figure 4. Overhanging geometry and forces exerted on the incipient failure block

\subsubsection{Fluvial erosion}

The flow field was calculated using a uniform flow model (Sturm, 2001) on a coarse lateral 1D grid cell, considering the sidewall correction effect in the narrow laboratory channel (called Process 1 in Figure 5), written as

1. $u_{j}=\frac{1}{n} R_{j}^{2 / 3} i^{1 / 2}$

where $u_{j}$ is the velocity in each calculated cell, $n$ is the Manning roughness parameter along the channel $(0 \cdot 011)$, calculated using the Manning-Strickler equation $\left(k_{\mathrm{s}}^{1 / 6} / 7 \cdot 66 \mathrm{~g}^{1 / 2}\right)$ in which $\boldsymbol{g}$ is gravitational acceleration $\left(9.81 \mathrm{~m} / \mathrm{s}^{2}\right)$ and $k_{\mathrm{s}}$ is the relative roughness height, defined as $1-3 d_{50}\left(1 \cdot 5 d_{50}\right), R_{j}$ is the hydraulic radius in each calculated cell $\left(A_{j} / P_{j}\right), A_{j}$ being the cross-sectional area in each calculated cell and $P_{j}$ being the perimeter length in each calculated cell, $i$ is the bed slope and $j$ is the lateral calculated cell number. For this study, the Manning roughness parameter was in the range of a hydraulically smooth channel $(0.01<n<0.02)$ (Julien, 2002). In addition, the mean diameter $\left(d_{50}\right)$ of the sediment mixture was smaller than the pure sand sediment. As a result, the Manning roughness parameter of the sediment mixture was smaller than that of the pure sand sediment, this value still being in the range of a hydraulically smooth channel. Therefore, the influence of silt-clay content was neglected for estimating the Manning roughness parameter in this study.

For fluvial erosion, calculation of the bank erosion rate was required to determine the hydraulic parameters and riverbank geometries (Process 2 in Figure 5). The set of equations for fluvial erosion consists of three main equations - namely, one for the erosion coefficient $(E)$, one for the depth-averaged bank erosion rate from fluvial erosion $\bar{\xi}$ and one for the bank erosion rate $\left(M_{\mathrm{e}}\right)$ (Duan, 2005).

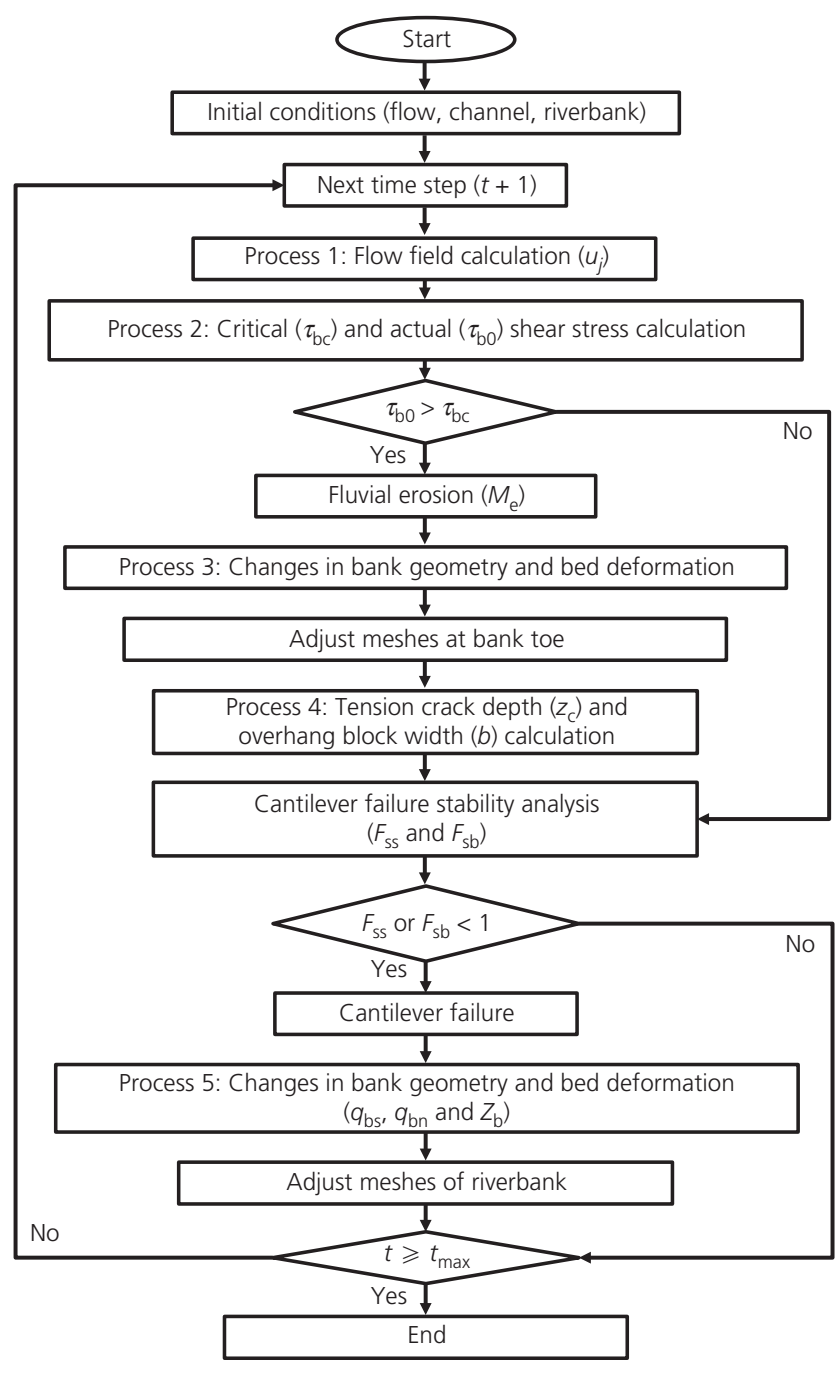

Figure 5. Logic diagram of the computational sequence 
The erosion coefficient is expressed by

2. $E=\sin \bar{\beta} \sqrt{\frac{C^{\prime} \mathrm{L}}{2 \rho_{\mathrm{s}}}}\left(1-C_{*} \cos \bar{\beta}\right)$

where $E$ is the erosion coefficient $\left(\left(\mathrm{m}^{3} / \mathrm{kg}\right)^{1 / 2}\right), \bar{\beta}$ is the average cohesive riverbank angle, $C_{\mathrm{L}}^{\prime}$ is the coefficient of the lift force $\left(C_{\mathrm{L}}^{2} \ln ^{2}\left(0 \cdot 35 d_{50} / k_{\mathrm{s}}\right) / \kappa^{2}\right)\left(C_{\mathrm{L}}\right.$ is the coefficient of the lift force near the riverbank surface $(0 \cdot 178), \kappa$ is the von Kármán constant $(0 \cdot 4)), \quad \rho_{\mathrm{s}}$ is the density of sediment particles $\left(2650 \mathrm{~kg} / \mathrm{m}^{3}\right)$, and $C_{*}$ is the ratio of the equilibrium concentration of the suspended sediment $(0 \cdot 25)$.

The depth-averaged bank erosion rate from fluvial erosion $(\bar{\xi})$ $(\mathrm{m} / \mathrm{s})$ can be quantified using an excess shear stress formula given by

3. $\bar{\xi}=E\left(1-\frac{\tau_{\mathrm{bc}}}{\tau_{\mathrm{b} 0}}\right)^{3 / 2} \sqrt{\tau_{\mathrm{b} 0}}$

where $\tau_{\mathrm{b} 0}$ is the actual shear stress $(\mathrm{Pa})\left(\rho \mathrm{g} u^{2} / c_{\mathrm{c}}^{2}\right), \rho$ is the density of water $\left(1000 \mathrm{~kg} / \mathrm{m}^{3}\right), c_{\mathrm{c}}$ is Chezy's roughness coefficient $\left(26 \cdot 53 D^{1 / 6} / d_{50}^{1 / 6}\right)$ and $D$ is the water depth. The critical shear stress $\left(\tau_{\mathrm{bc}}\right)$ is estimated based on the percentage of siltclay content (SC), which is obtained as (Julian and Torres, 2006; Vanoni, 1977)

$$
\begin{aligned}
\tau_{\mathrm{bc}}= & 0 \cdot 1+0 \cdot 1779(\mathrm{SC})+0 \cdot 0028(\mathrm{SC})^{2} \\
& -2.34 \times 10^{-5}(\mathrm{SC})^{3}
\end{aligned}
$$

In Equation 3, only the portion of the riverbank where the actual shear stress is more than the critical shear stress is considered for the fluvial erosion estimation.

The rate of bank erosion can be considered proportional to the rate of depth-averaged bank erosion and can be expressed as

\section{4. $M_{\mathrm{e}}=e \bar{\xi}$}

where $M_{\mathrm{e}}$ is the rate of bank erosion $(\mathrm{m} / \mathrm{s})$ and $e$ is a coefficient that reflects the effect of a bank failure. The coefficient $e$ can be determined by solving a series of equations with the functions of riverbank height and overhanging block dimensions, based on a heuristic approach. Further information is given by Duan (2005).

For the computational process of fluvial erosion, the bank profiles are deformed to accord with the fluvial erosion simulated at the end discrete timestep (Process 3 in Figure 5). Therefore,

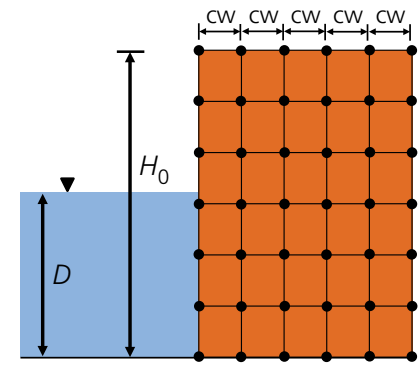

(a)

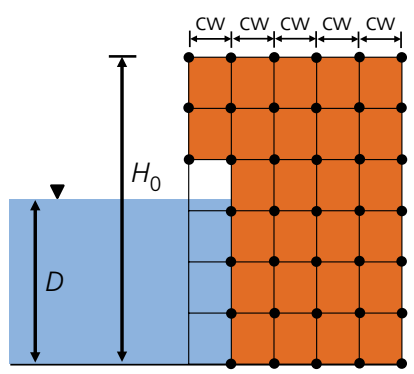

(b)
Figure 6. Two schemes used to adopt the boundary nodes by the effect of fluvial erosion: (a) unmodified boundary nodes; (b) modified boundary nodes

the undisturbed cell occupation rate $(\Omega)$ is achieved as expressed in Equation 5 through two possible schemes (see Figure 6).

5. $\Omega_{t}=\frac{\sum_{t=1}^{n} \mathrm{FE}}{\mathrm{CW}}$

where $\mathrm{CW}$ is the width (in $\mathrm{m}$ ) of a calculated cell of the cohesive riverbank, estimated by the cohesive riverbank width divided by the number of calculated grid cells in the cohesive riverbank in the lateral direction, and FE is the simulated fluvial erosion in each timestep using Equation 4.

For the first scheme, if the accumulated magnitude of the simulated fluvial erosion is less than the width of a calculated cell of the cohesive riverbank, the boundary nodes are not shifted horizontally inward through fluvial erosion (Figure 6(a)). For the second scheme, if the accumulated fluvial erosion is equal to or larger than the width of a calculated cell of the cohesive riverbank, the new grid cells are assigned to the new cohesive riverbank profile nodes (Figure 6(b)).

\subsubsection{Cantilever failure}

For a cantilever failure, the overhanging failure blocks were defined by considering the safety factor for two types of failure (i.e. based on shear and beam failure mechanisms) (Abam, 1997; Thorne and Tovey, 1981); tensile failure was omitted because such failures have rarely been observed along actual rivers (Darby et al., 2007). A cantilever failure will occur if any of the overhanging blocks have a safety factor of less than one (Process 4 in Figure 5). The two types of cantilever failure mechanisms applied in this study are described by Abam (1997).

Shear failure involves shear stress along the vertical plane. Such failure is expected when the shear stress along the vertical plane from the weight of the overhanging block (FD) exceeds 
the cohesive force (FR), as shown in Figure 4. The safety factor of shear failure $\left(F_{\mathrm{ss}}\right)$ is given by

6. $\quad F_{\mathrm{ss}}=\frac{C\left(H^{\prime}-z_{\mathrm{c}}\right)}{2 \gamma b H^{\prime}}$

where $C$ is the compressive strength per unit length $(\mathrm{kN} / \mathrm{m}), H^{\prime}$ is the overhanging block height $(\mathrm{m}), \gamma$ is the unit weight of soil $\left(\mathrm{kN} / \mathrm{m}^{3}\right), b$ is the overhanging block width $\left(C\left(T_{\mathrm{z}}^{2}\right) / 2 \gamma H^{\prime}\right)$ as determined by Abam (1997) and $z_{\mathrm{c}}$ is the maximum depth of a tension crack $(2 C / \gamma \tan (\pi / 4+\phi / 2))\left(T_{\mathrm{z}}\right.$ is the tensile zone length (m) and $\phi$ is the internal friction angle) based on the location of the overhanging block width (Terzaghi et al., 1996). However, the tension crack depth for this study was assumed to be 0.5 of the overhanging block height because the ratio of tension crack depth to overhanging block height $(0 \cdot 3-0 \cdot 7)$ does not typically change the factor of safety by more than $10 \%$ (Thorne and Abt, 1993).

Beam failure is related to unstable overhanging blocks rotating from the cohesive riverbank forward into the channel. This occurs when the rotational moment at the neutral axis from the weight of the block subject to cantilever failure $(M)$ exceeds the restoring moment of cohesive force. The safety factor of a beam failure $\left(F_{\mathrm{sb}}\right)$ can be described by

7. $\quad F_{\mathrm{sb}}=\frac{T\left(T_{\mathrm{z}}^{2}\right)}{2\left[\gamma b^{2} H^{\prime}-C\left(C_{\mathrm{z}}^{2} / 2\right)\right]}$

where $T$ is the tensile strength per unit length $(\mathrm{kN} / \mathrm{m})$ and $C_{\mathrm{z}}$ is the compressive zone length (m).

\subsubsection{Bedload transport and bed deformation}

After fluvial erosion and a cantilever failure, the failure materials were dropped into the channel and assumed to be non-cohesive materials and bedload (Process 5 in Figure 5). The equations describing the bedload transport and bed deformation are as follows.

The sediment transport rate in the streamwise direction $\left(q_{\mathrm{bs}}\right)$ was calculated using the formula proposed by Ashida and Michiue (1972)

8. $\quad q_{\mathrm{bs}}=17 \tau_{*}^{3 / 2}\left(1-\frac{\tau_{* \mathrm{c}}}{\tau_{*}}\right)\left(1-\sqrt{\frac{\tau_{* \mathrm{c}}}{\tau_{*}}}\right) \sqrt{S_{\mathrm{g}} \boldsymbol{g} d_{50}^{3}}$

where $\tau_{*}$ is the non-dimensional bed shear stress $\left(u^{*} /\left(S_{\mathrm{g}} g d_{50}\right)\right)$, $u^{*}$ is the shear velocity $\left(\sqrt{\mathbf{g} R_{j}}\right), S_{\mathrm{g}}$ is the specific weight of sediment $(2 \cdot 65)$ and $\tau_{* \mathrm{c}}$ is the non-dimensional critical bed shear stress, using the formula of Iwagaki (1956).
The sediment transport rate in the lateral direction $\left(q_{\mathrm{bn}}\right)$ was calculated using the formula of Hasegawa (1984) by neglecting the effect of a secondary current as follows

9. $\quad q_{\mathrm{bn}}=-q_{\mathrm{bs}} \sqrt{\frac{\tau_{* \mathrm{c}}}{\mu_{\mathrm{s}} \mu_{\mathrm{k}} \tau_{*}}} \frac{\partial Z_{\mathrm{b}}}{\partial y}$

where $\mu_{\mathrm{s}}$ is the static friction coefficient $(1 \cdot 0), \mu_{\mathrm{k}}$ is the kinetic friction coefficient $(0 \cdot 45), Z_{\mathrm{b}}$ is the bed elevation in the calculated cell and $y$ is the coordinate component in the lateral axis.

The bed deformation was calculated using a continuity equation of sedimentation transport in an orthogonal coordinate, expressed as

10. $\frac{\partial Z_{\mathrm{b}}}{\partial t}+\frac{1}{1-\lambda}\left(\frac{\partial q_{\mathrm{bn}}}{\partial y}\right)=0$

where $t$ is time and $\lambda$ is the porosity of the material $(0 \cdot 4)$, which is in the range of general values of riverbanks and riverbeds (Dulal et al., 2010; Iwasaki et al., 2012). Moreover, the silt proportion in the sediment mixture was washed away to the downstream end of the flume after the fluvial erosion and cantilever failures in the experimental results. Therefore, the process of bed deformation in this study was considered only in pure sand sediment.

\section{Results and discussion}

\subsection{Experimental results}

A summary of cantilever failure during each experiment is given with reference to images of spatial bank width observed in the experiments (illustrated through the results of case 6 in Figure 7) and to schematic diagrams of spatial bank width using top-view video cameras, as shown in Figure 8. The failure processes determined in the experimental studies are as follows.

In case 1, fluvial erosion occurred immediately, during the initial stage. The riverbank rotated into the channel approximately $1 \mathrm{~min}$ after the wooden panel was removed and the experiment was started, because the material was cohesionless.

- In case 2, from the initial time to $t=13 \mathrm{~min}$, fluvial erosion occurred at the bank toe, whereas the first tension crack developed progressively at the upper surface at 13 min $45 \mathrm{~s}$. At about 14 min, a beam failure occurred at the downstream end, followed by a beam failure at the upstream end at $19 \mathrm{~min}$. A large tension crack and beam failure developed at the upstream end at $23 \mathrm{~min} 34 \mathrm{~s}$ and at $24 \mathrm{~min}$. The experiment ended at $34 \mathrm{~min}$. 


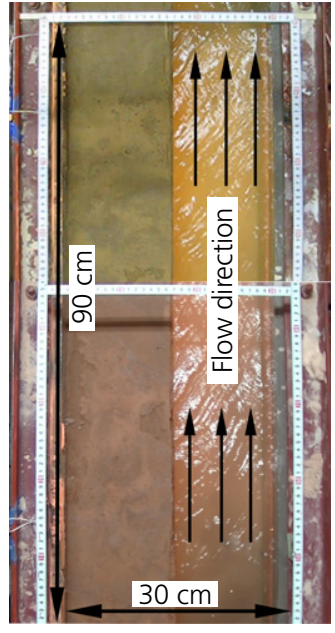

(a)

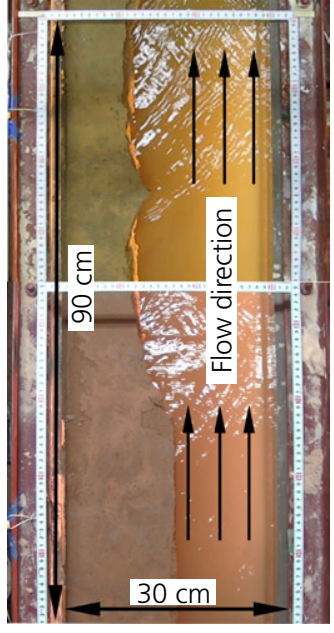

(b)

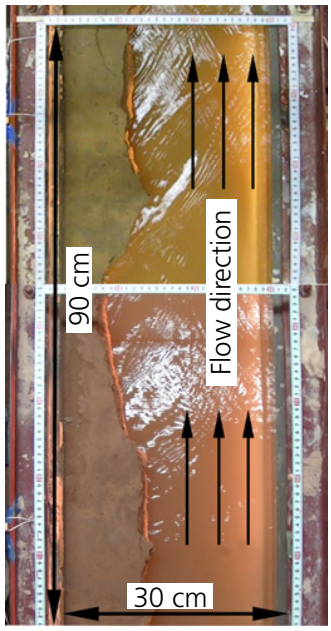

(c)

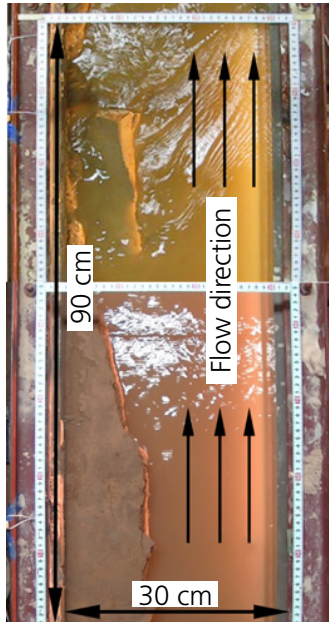

(d)

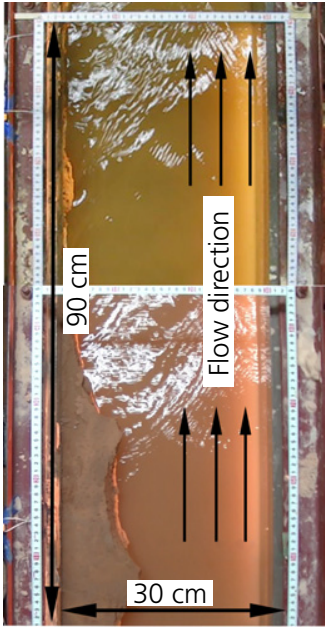

(e)

Figure 7. Experimental images of spatial bank width in case 6 : (a) initial stage; (b) $10 \mathrm{~min}$; (c) $13 \mathrm{~min}$; (d) $16 \mathrm{~min}$; (e) $20 \mathrm{~min}$

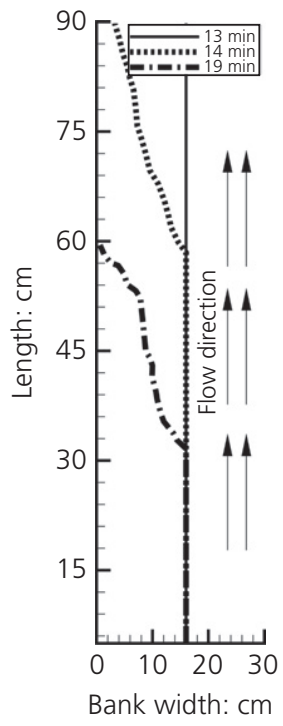

(a)

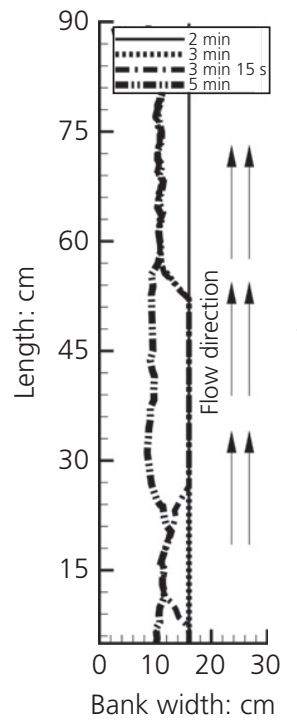

(b)

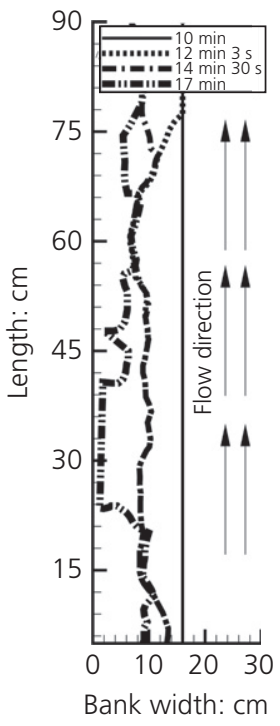

(c)

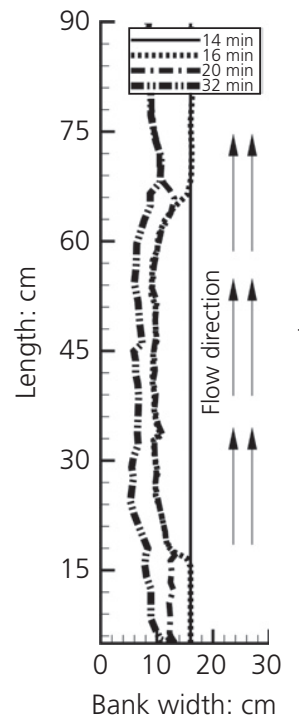

(d)

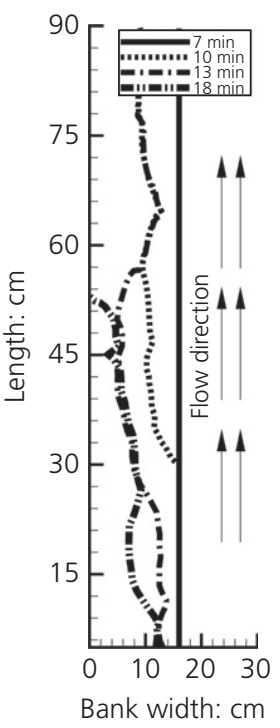

(e)

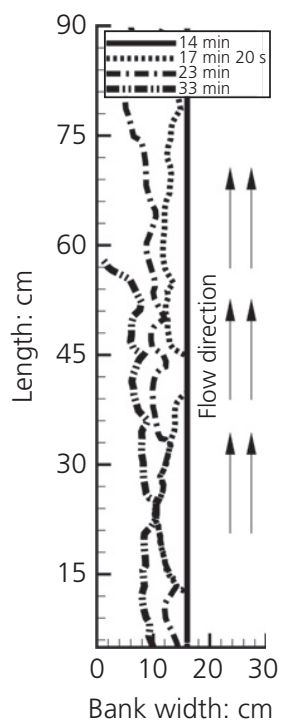

(f)

Figure 8. Schematic diagrams of spatial bank width: (a) case 2; (b) case 3; (c) case 4; (d) case 5; (e) case 6; (f) case 7

- In case 3, fluvial erosion dominated from the initial time up to $3 \mathrm{~min}$. Four tension cracks and beam failures occurred at $3 \mathrm{~min}, 3 \mathrm{~min} 15 \mathrm{~s}, 5 \mathrm{~min}$ and $6 \mathrm{~min} 30 \mathrm{~s}$. After beam failure, the bank slope reshaped towards an angle of approximately $90^{\circ}$. The experiment stopped at $8 \mathrm{~min} 30 \mathrm{~s}$.

- In case 4, fluvial erosion developed from the start time up to $10 \mathrm{~min}$. Six tension cracks and beam failures then occurred along the cohesive riverbank. The experiment ended at $18 \mathrm{~min} 30 \mathrm{~s}$.
In case 5, fluvial erosion occurred during the initial stage. The first considerable tension crack was observed in the middle region at $15 \mathrm{~min} 30 \mathrm{~s}$. From $16 \mathrm{~min}$ to $32 \mathrm{~min}$, five successive tension cracks and beam failures were captured along the cohesive riverbank. The experiment reached the equilibrium stage at $45 \mathrm{~min}$.

- In case 6, fluvial erosion occurred immediately after the wooden panel was removed. Tension cracks and beam failures were then observed in rapid succession at the downstream end at $10 \mathrm{~min}$, at the upstream end at $11 \mathrm{~min}$, 
$12 \mathrm{~min} 20 \mathrm{~s}$ and $13 \mathrm{~min}$, at the downstream end again at $14 \mathrm{~min}$ and $16 \mathrm{~min}$, and at the upstream end again at $17 \mathrm{~min}$ and $18 \mathrm{~min}$. The experiment reached the equilibrium stage at $20 \mathrm{~min}$.

In case 7, during the initial stage, fluvial erosion occurred along the bank but was more evident in the middle region. The first tension crack and beam failure were captured between $14 \mathrm{~min}$ and $15 \mathrm{~min} 25 \mathrm{~s}$. From $17 \mathrm{~min} 20 \mathrm{~s}$ to 33 min, 11 significant tension cracks and beam failures were observed along the riverbank. At $35 \mathrm{~min}$, the cohesive riverbank reached its final configuration because no failures occurred after this time.

The experiments showed that fluvial erosion has the greatest effect on the occurrence of cantilever failure instability because such erosion increases the width of an overhanging block (observed using side-view video cameras) but decreases its stability. This is because fluvial erosion is related to a loosening of weak bonds between the material particles. The observations from these experiments are similar to those of previous studies (Abam, 1997; Darby et al., 2007; Rinaldi and Nardi, 2013; Thorne and Tovey, 1981). Tension crack and beam failure processes were then observed and repeated intermittently until the final stage of failure. The tension cracks began to develop vertically downwards from the upper surface of the overhanging block, thereby reducing the effective length of the vertical failure surface and decreasing the riverbank stability. Moreover, tension cracks seemed to develop only when the cantilever was already close to failure. The dimensions of the failure block were $2 \cdot 97-9 \cdot 98 \mathrm{~cm}$ wide and $11 \cdot 76-62 \cdot 14 \mathrm{~cm}$ long (see Table 2). In terms of cantilever failure mechanisms, the experimental results are consistent with previous experiments, showing that beam failure is the dominant failure mechanism (Nardi et al., 2012; Samadi et al., 2013).

\subsection{Numerical results}

To assess the accuracy and reliability of the proposed model, the numerical results were compared with the experimental results in terms of the streamwise-averaged bank width and water level at each timestep, these being the average values of the bank width and water level along the centre part of the cohesive riverbanks. In addition, the numerical results were validated using the spatial bank width and water level.

Figure 9 shows cross-sectional views at two time stages, simulated using the numerical model. Figure 9(a) shows the fluvial erosion in the submerged zone. This process occurs through the fluvial entrainment of materials from the bank toe, leading to an undermining that produces an overhanging block. Figure 9 (b) shows the beam failure of a cohesive riverbank, which is a common mechanism of a cantilever failure. Following the drop process of the numerical model, the failure materials were assumed to be non-cohesive materials that come to rest at the intermediate drop point.

The numerical and experimental results of a cantilever failure were also compared with a perfect agreement line, which fell within a range of $25 \%$ error line in terms of streamwise average bank width and $20 \%$ error line in streamwise average

\begin{tabular}{|c|c|c|c|c|c|c|}
\hline Case & & I & $\|$ & III & IV & V \\
\hline \multirow[t]{3}{*}{2} & Failure time: $\min$ & $14 \cdot 00$ & $19 \cdot 00$ & $24 \cdot 00$ & $30 \cdot 00$ & - \\
\hline & Width: cm & $8 \cdot 36$ & $8 \cdot 30$ & $6 \cdot 29$ & $5 \cdot 21$ & - \\
\hline & Length: cm & $31 \cdot 35$ & $28 \cdot 46$ & $27 \cdot 99$ & $11 \cdot 76$ & - \\
\hline \multirow[t]{3}{*}{3} & Failure time: $\min$ & $3 \cdot 00$ & $3 \cdot 15$ & $3 \cdot 25$ & $4 \cdot 30$ & $5 \cdot 00$ \\
\hline & Width: $\mathrm{cm}$ & $5 \cdot 57$ & $2 \cdot 97$ & $5 \cdot 41$ & 4.03 & $9 \cdot 98$ \\
\hline & Length: cm & 34.53 & $12 \cdot 04$ & $22 \cdot 24$ & $14 \cdot 50$ & $28 \cdot 33$ \\
\hline \multirow[t]{3}{*}{4} & Failure time: $\min$ & $12 \cdot 00$ & $14 \cdot 00$ & $16 \cdot 00$ & $17 \cdot 00$ & $18 \cdot 00$ \\
\hline & Width: cm & $6 \cdot 30$ & $7 \cdot 55$ & 3.95 & $7 \cdot 30$ & 5.63 \\
\hline & Length: cm & $59 \cdot 70$ & $18 \cdot 2$ & $13 \cdot 25$ & $27 \cdot 62$ & $44 \cdot 46$ \\
\hline \multirow[t]{3}{*}{5} & Failure time: $\min$ & $15 \cdot 00$ & $16 \cdot 00$ & $19 \cdot 00$ & $19 \cdot 30$ & $30 \cdot 00$ \\
\hline & Width: $\mathrm{cm}$ & $5 \cdot 76$ & $6 \cdot 08$ & $6 \cdot 31$ & 3.06 & $3 \cdot 95$ \\
\hline & Length: cm & $29 \cdot 41$ & $18 \cdot 53$ & $24 \cdot 87$ & $14 \cdot 76$ & $62 \cdot 14$ \\
\hline \multirow[t]{3}{*}{6} & Failure time: $\min$ & 8.00 & $8 \cdot 30$ & $8 \cdot 40$ & $11 \cdot 00$ & $13 \cdot 00$ \\
\hline & Width: cm & $5 \cdot 07$ & $5 \cdot 01$ & $6 \cdot 84$ & $3 \cdot 29$ & $5 \cdot 22$ \\
\hline & Length: cm & $13 \cdot 22$ & $19 \cdot 27$ & $22 \cdot 37$ & $19 \cdot 21$ & $34 \cdot 50$ \\
\hline \multirow[t]{3}{*}{7} & Failure time: $\min$ & $15 \cdot 25$ & $17 \cdot 40$ & $21 \cdot 10$ & $23 \cdot 00$ & $33 \cdot 00$ \\
\hline & Width: cm & $3 \cdot 86$ & $3 \cdot 15$ & $4 \cdot 01$ & $3 \cdot 15$ & $4 \cdot 24$ \\
\hline & Length: cm & $20 \cdot 98$ & $15 \cdot 02$ & $13 \cdot 72$ & $29 \cdot 58$ & $17 \cdot 98$ \\
\hline
\end{tabular}

Table 2. Summary of failure times and failure block dimensions 


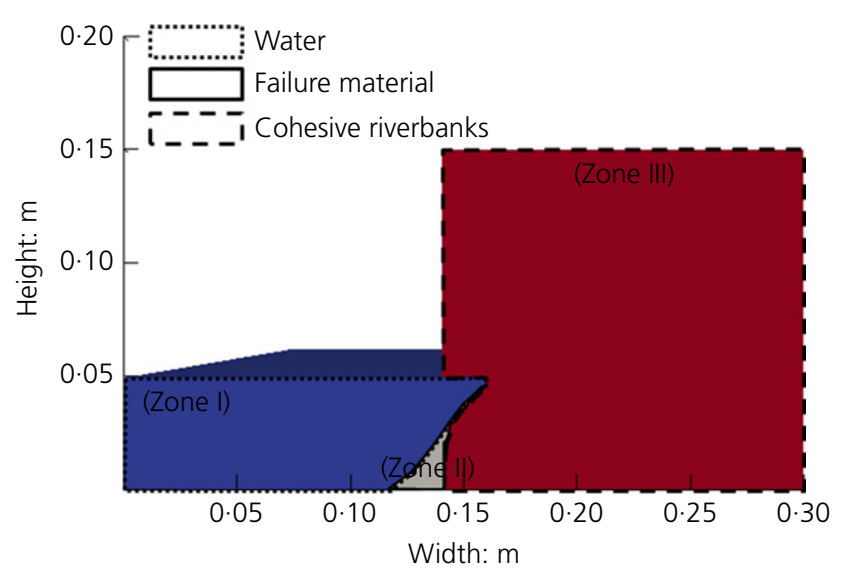

(a)

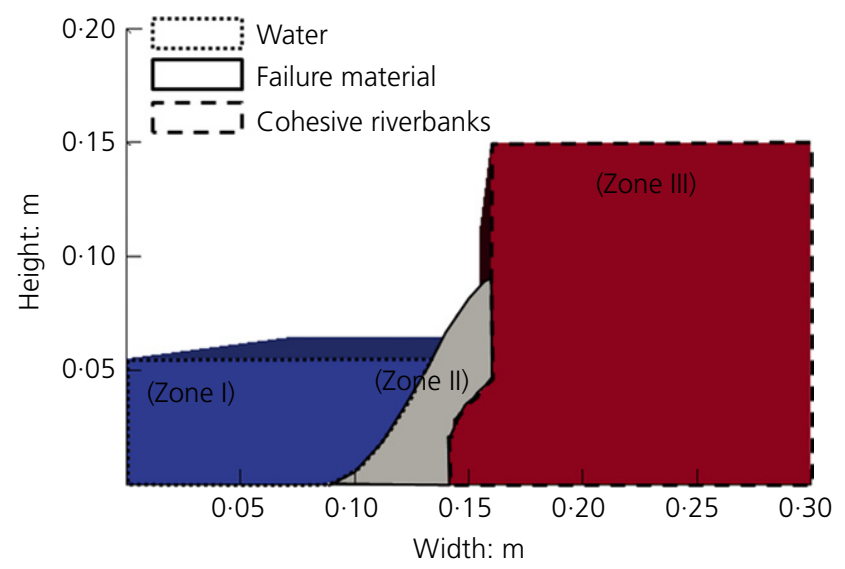

(b)

Figure 9. Cross-sectional views of (a) fluvial erosion and (b) beam failure mechanism of case 3 (zones I, II and III are water, failure material and cohesive riverbank, respectively)

water level, as shown in Figure 10. Several points fell outside the $25 \%$ error line (case 2 and case 4 ), which is why the numerical modelling did not consider the effect of the slump blocks. The effect of slump blocks on the riverbed in front of the riverbank where it forms a sediment buffer that reinforces riverbanks and reduces fluvial erosion is described by Crosato (2008).

The relationship of streamwise-averaged water levels indicates that the calculated water level shows an increasing trend whereas the water surface stayed at a constant level during the experiments. This is because the failure materials in the experiments were washed away to the downstream region of the experimental flume whereas, in the numerical modelling, it was assumed that the failure materials were dropped at an intermittent drop point. When failure materials are dropped into the channel, the water level will increase along the channel. Nevertheless, the streamwise-averaged bank width and water level in the numerical simulations show relatively high degrees of accuracy, with errors fluctuating from $20-25 \%$ of the experimental results.

Regarding the validation of spatial bank width and water level, the numerical model satisfactorily replicated the experimental results. As an example, the validation results of spatial bank width and water level for case 6 at 10, 11 and $13 \mathrm{~min}$ are shown in Figure 11 and Figure 12, respectively.

\subsection{Discussion}

For the flow conditions studied, the Reynolds numbers (Re) were within the range of 15000 to 40000 and the Froude numbers (Fr) were smaller than one (Table 1), which correspond to turbulent flow and subcritical flow regimes, respectively. Generally, the Froude number is adopted here to represent a large number of alluvial rivers where the flow condition is subcritical flow (Dulal and Shimizu, 2010; Lewin, 1976; Peakall et al., 2007). Moreover, the channel aspect ratio was less than five (i.e. the flume width was less than five times the flow depth). That ratio is smaller than the aspect ratio of real rivers, but the smaller aspect ratio was chosen in order to clearly replicate the cantilever failure in the experimental flume. To overcome the aspect ratio discrepancy between the experimental flume and real rivers, the sidewall correction method was considered essential for this study. In the numerical model, the sidewall correction effect was calculated by a dividing channel method in which the streamwise velocity was calculated separately on each coarse lateral 1D grid cell.

For the experimental results, experiments using different overhanging block heights and cohesive forces were conducted to identify the effect of the overhanging block stability. The results indicate that the overhanging block height and cohesive force have a significant impact on the overhanging block stability (Samadi et al., 2011). For example, the experimental results show that the total experiment time for a higher bank (20 cm in case 2) was longer than that of a lower bank $(15 \mathrm{~cm}$ in case 3). The main reason for that is the larger failure of the higher bank's materials dropping into the channel and being strongly protected from new fluvial erosion at the bank toe. Furthermore, the rate of fluvial erosion in case $3(\mathrm{SC}=30 \%)$ was greater than that in case $5(\mathrm{SC}=20 \%)$ under similar hydraulic conditions in the experimental and numerical results, as shown by the temporal average bank width in Figure 13(a). For case 3, the experiment was stopped at $8 \mathrm{~min} 30 \mathrm{~s}$ when failure proceeded throughout all of the cohesive riverbanks. Moreover, the case 5 experiment reached the equilibrium stage at 45 min because riverbanks with a higher silt-clay content are more susceptible to failure than those with lower silt-clay contents. Observations from other works are similar in terms of changing silt-clay content (Couper, 2003; Dulal and Shimizu, 2010; Julian and Torres, 2006). For the numerical results, the rate of fluvial erosion in case 3 was greater than that in case 5 under similar conditions, as shown in Figure 13(b). Moreover, the numerical results are consistent 


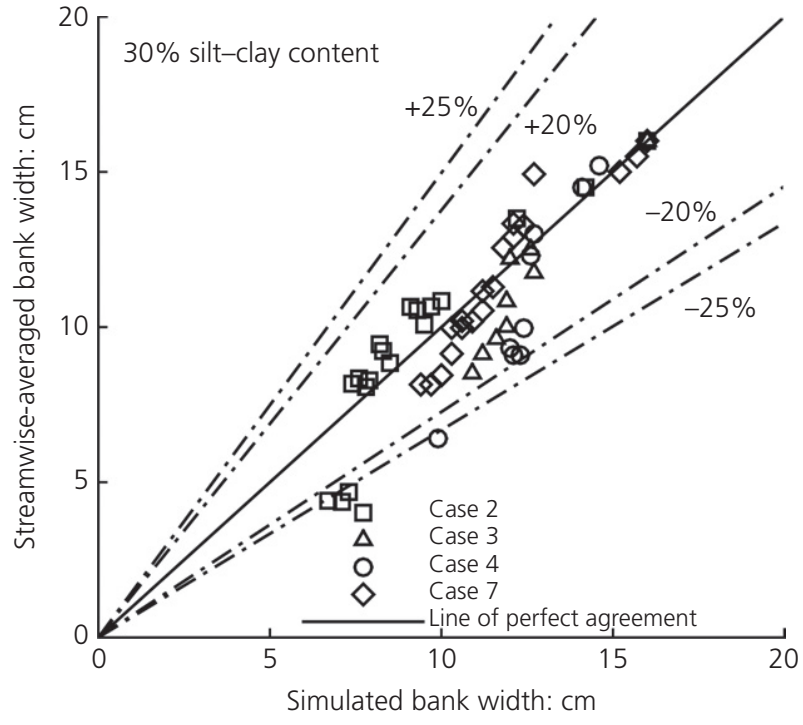

(a)

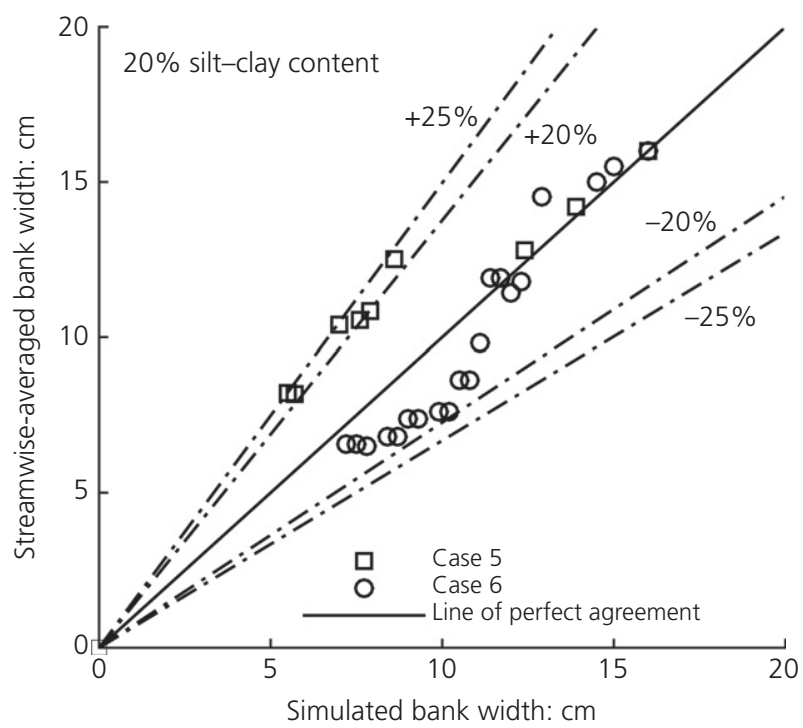

(c)

Figure 10. Comparison of numerical results and spatially averaged experimental results for bank width and water level and silt-clay contents of $30 \%$ and $20 \%$

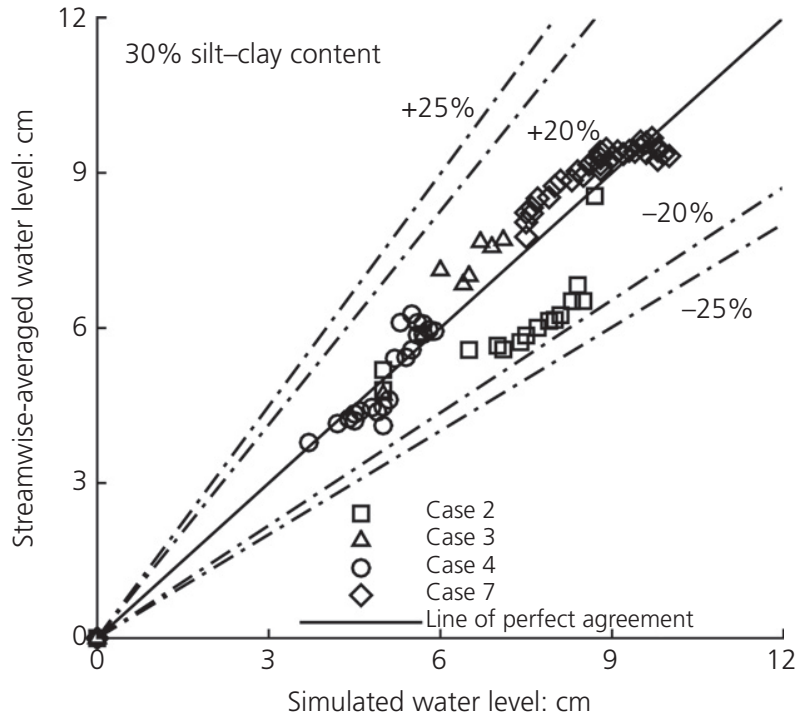

(b)

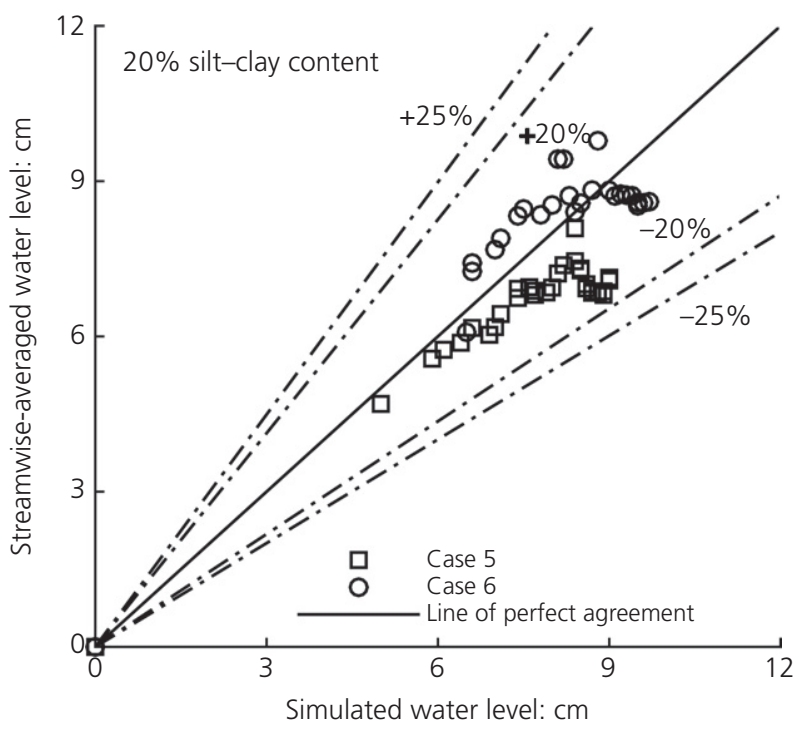

(d) with the experimental results with regards to the changing percentage of silt-clay content.

Another significant parameter in cantilever failure is the cohesive force. The cohesive force of riverbanks is related mainly to the percentage of silt-clay content (Couper, 2003; Dulal and Shimizu, 2010; Julian and Torres, 2006) and water content (Couper, 2003; Rinaldi and Nardi, 2013; Thorne and Tovey, 1981). Additionally, the percentage of silt-clay content could be expected to have some bearing on the susceptibility of cohesive riverbanks to subaerial erosion processes, as cohesive materials with a high silt-clay content have greater plasticity and hence capacity for swelling and shrinkage. For overhanging block stability, the cohesive force is a main parameter for calculating the safety factor of the overhanging block in Equations 6 and 7. In both equations, the safety factor of an overhanging block with a high cohesive force is larger than the safety factor of an overhanging block with low cohesive force.

The experiments were able to randomly reproduce a cantilever failure - as illustrated in Figure 8 - and some of the 


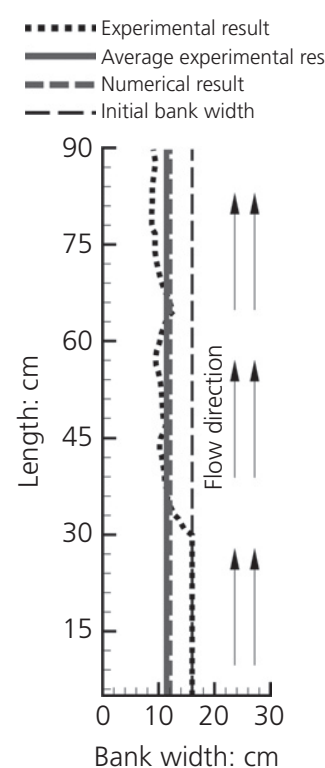

(a)
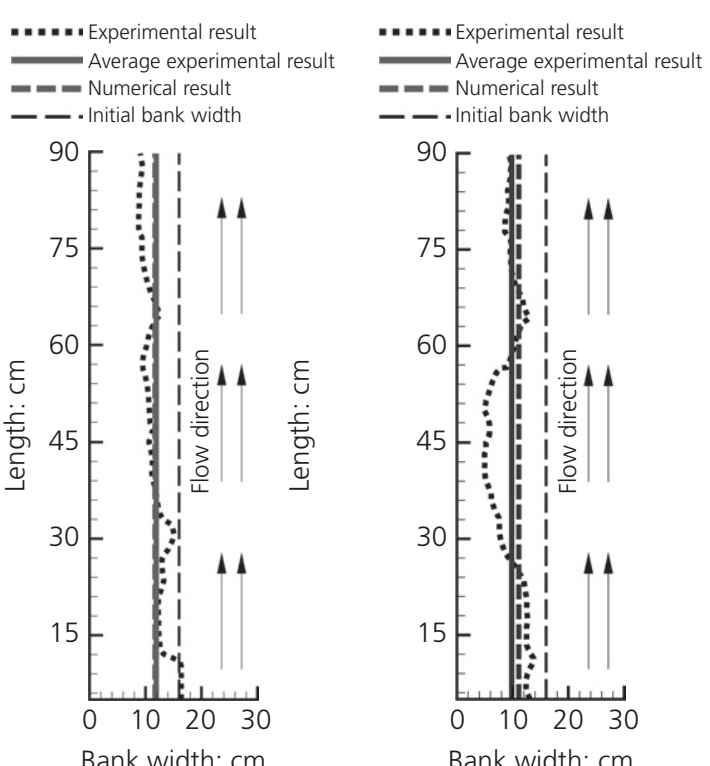

(b)

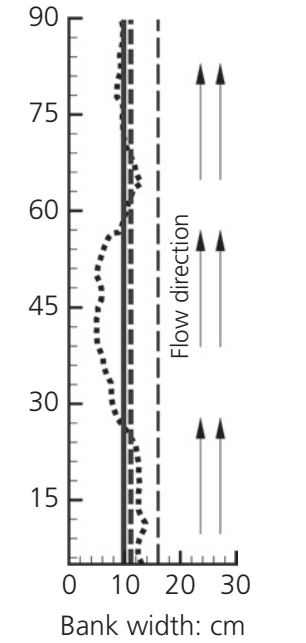

(c)

Figure 11. Validation results for spatial bank width in case 6:

(a) $10 \mathrm{~min}$; (b) $11 \mathrm{~min}$; (c) $13 \mathrm{~min}$

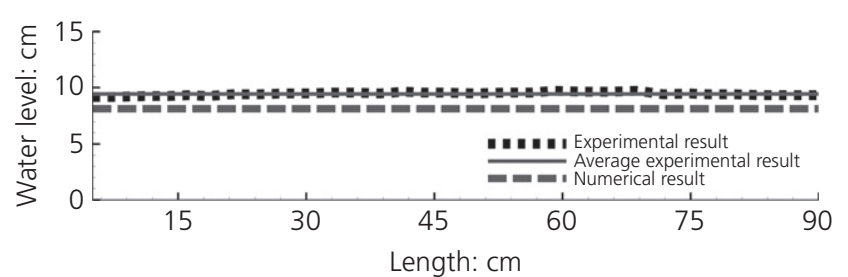

(a)

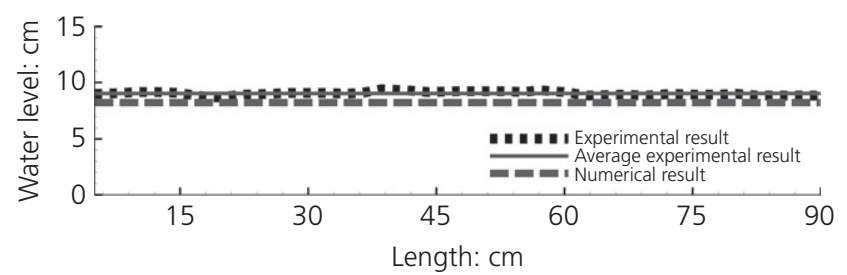

(b)

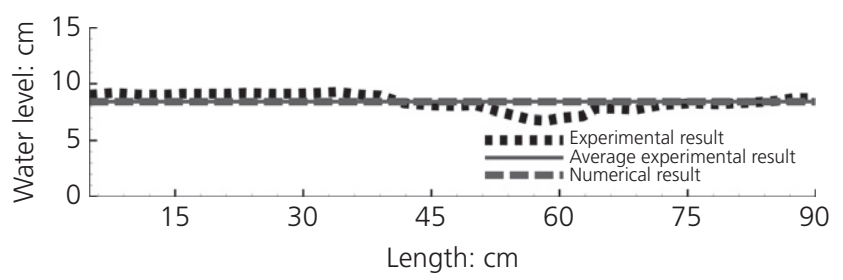

(c)

Figure 12. Validation results for spatial water level in case 6: (a) $10 \mathrm{~min}$; (b) $11 \mathrm{~min}$; (c) $13 \mathrm{~min}$

experimental results showed the backward erosion process. Furthermore, most of the experimental results in the case of high actual shear stress (high discharge) showed backward erosion, which is similar to previous observations (Hooke, 1980; Laubel et al., 2003). In the present study, riverbank particles were detached from the downstream region through the effect of a second wooden panel by the generation of a reverse flow. This process is summarised as follows. The flow from the channel hits the second wooden panel and is reversed, with high velocity, to erode the cohesive riverbank at the downstream region. For this reason, this study considered only the centre region and used streamwise-averaged data of cohesive banks to reduce the effect of the wooden panel. Experimental limitations were the effect of scale and the friction factor between the cohesive riverbanks and experimental wall. The experiments were conducted at a smaller scale than the prototype because it was hoped to obtain cantilever failure information in expected patterns of response more rapidly and with a closer control over the model details than would be possible using a full-scale experiment (Muir, 2004; Samadi et al., 2013).

As in the numerical model, the present uniform flow model has limitations in reproducing variations of the phenomena in the streamwise direction of an eroded bank. Therefore, a 2D depth-averaged model is needed to reproduce the flow fields of eroded non-uniform riverbanks along a channel (Bahar and Fukuoka, 2002). Moreover, the present numerical model is a simple cross-sectional 2D model. Such a model is limited in its ability to simulate non-uniform cantilever failure, the longitudinal gradient of sediment transport and pore water pressure. The proposed model should thus be improved in future research so that it considers the effect of such phenomena. 


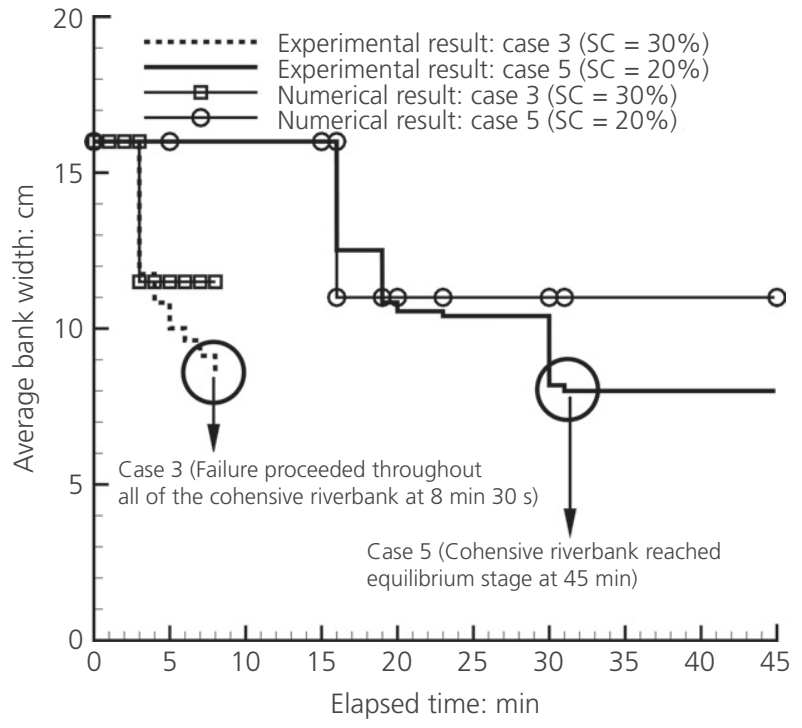

(a)

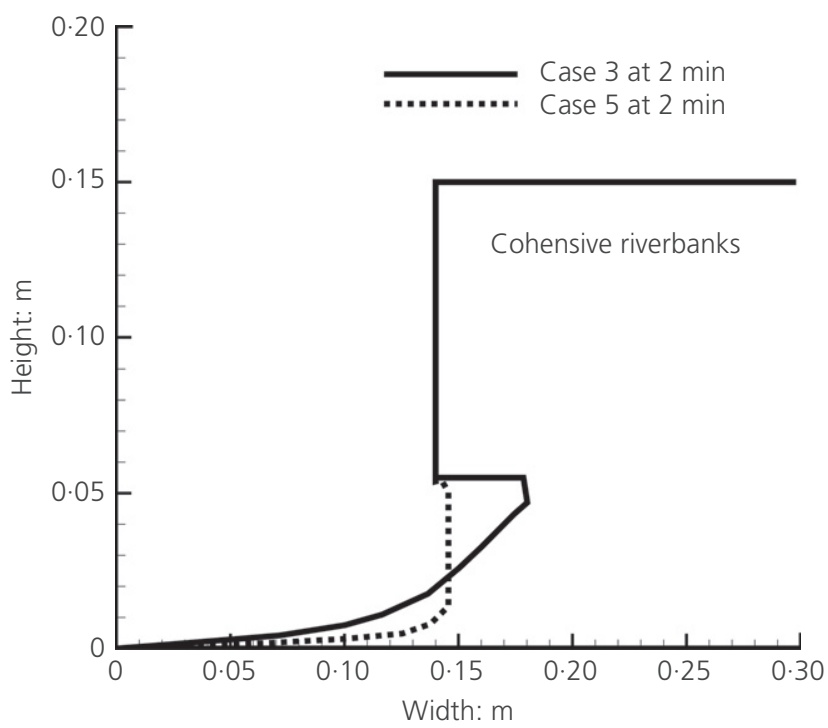

(b)

Figure 13. Comparison of results with different cohesive forces for case 3 (SC $=30 \%$ ) and case 5 (SC = 20\%): (a) experimental and numerical results for average bank width; (b) numerical results for riverbank geometry

\section{Conclusions}

This study elucidated the mechanisms of cantilever failure by means of laboratory experiments and numerical modelling. In the laboratory experiments, three types of cohesive materials with different percentages of silt-clay content were investigated in seven cases by varying the hydraulic conditions. The novel numerical modelling of a cantilever failure implemented by a triple-grid approach within the framework of fluvial erosion and the cantilever's subsequent failure was validated by the experimental results. The main conclusions from the results are as follows.

For the mechanism of a cantilever failure, the experimental results showed that fluvial erosion at the lower part generates an overhanging block in the upper part of cohesive riverbanks. Tension cracks then develop at the upper surface of the cohesive riverbanks. Such tension cracks seem to develop only when the cantilever is already close to failure. After that, cantilever failure occurred along the tension crack line. The dominant failure mechanism was observed to be beam failure, which is consistent with the findings of previous researchers who have suggested that beam failure may be prevalent (e.g., Darby et al., 2007; Samadi et al., 2011, 2013; Thorne and Tovey, 1981). Moreover, the results indicate that cohesive riverbanks with higher silt-clay contents are more susceptible to failure than those with lower silt-clay contents. The observations from this work are similar to previous studies in term of changing silt-clay content (Couper, 2003; Dulal and Shimizu, 2010; Julian and Torres, 2006).

The developed numerical model can satisfactorily reproduce fluvial erosion at the lower part of cohesive riverbanks and beam failure at an overhanging block of cohesive riverbanks. Additionally, the numerical model shows good agreement with the experimental results in terms of the spatial-averaged bank width and water level along cohesive riverbanks. The experimental results were presented and compared qualitatively with the numerical results. It is, however, still necessary to examine the validity of the slump block model for this work and compare the calculated results with more experimental studies and local observations.

\section{Acknowledgements}

The authors would like to express sincere thanks to the Japanese Government Scholarships for financial support. Soil mechanics laboratory tests were carried out at Hokkaido University, with partial support from Mr Anand Panta.

\section{REFERENCES}

Abam TKS (1997) Genesis of channel bank overhangs in the Niger Delta and analysis of mechanisms of failure. Geomorphology 18(2): 151-164.

ASCE (ASCE Task Committee on Hydraulics, Bank Mechanics, and Modeling of River Width Adjustment) (1998) River width adjustment. I: processes and mechanisms. Journal of Hydraulic Engineering ASCE 124(9): 881-902.

Ashida M and Michiue M (1972) Study on hydraulic resistance and bedload transport rate in alluvial stream. Proceedings of the Japan Society of Civil Engineers 206: 59-69 (in Japanese).

ASTM (1996) D 2435-96: Standard test method for onedimension consolidation properties of soils. ASTM International, West Conshohocken, PA, USA. 
ASTM (1998) D 3080-98: Standard test method for onedirectional consolidation properties of soils. ASTM International, West Conshohocken, PA, USA.

Bahar SMH and Fukuoka S (2002) Study of cohesive riverbank erosion mechanism through analysis of flow fields near and inside eroded bank. Annual Journal of Hydraulic Engineering JSCE 46: 749-754.

Couper P (2003) Effects of silt-clay content on the susceptibility of river banks to subaerial erosion. Geomorphology 56(1-2): 95-108.

Crosato A (2008) Analysis and Modeling of River Meandering. $\mathrm{PhD}$ dissertation, Delft University of Technology, Delft, The Netherlands.

Dapporto S, Rinaldi M, Casagli N and Vannocci P (2003) Mechanism of river failure along the Arno River, central Italy. Earth Surface Processes and Landforms 28(12): 233-245.

Darby SE, Rinaldi M and Dapporto S (2007) Coupled simulations of fluvial erosion and mass wasting for cohesive river banks. Journal of Geophysical Research 112(F3): F03022, http://dx.doi.org/10.1029/2006JF000722.

Duan JG (2005) Analytical approach to calculate rate of bank erosion. Journal of Hydraulic Engineering ASCE 131(11): 980-990.

Duan JG and Julien PY (2010) Numerical simulation of meandering evolution. Journal of Hydrology 391(S1-2): 34-46.

Dulal KP and Shimizu Y (2010) Experimental simulation of meandering in clay mixed sediments. Journal of Hydro-environment Research 4(4): 329-343.

Dulal KP, Kobayashi K, Shimizu Y and Parker G (2010) Numerical computation of free meandering channels with the application of slump blocks on the outer bends. Journal of Hydro-environment Research 3(4): 239-246.

Fukuoka S, Watanabe A, Katayama Tet al. (1999) Erosion expansion mechanism of cohesive (silt) bank by the stream flow. Annual Journal of Hydraulic Engineering JSCE 43: 695-700 (in Japanese).

Hasegawa K (1984) Hydraulic Research on Planimetric Forms, Bed Topographies and Flow in Alluvial River. $\mathrm{PhD}$ dissertation, Hokkaido University, Sapporo, Japan (in Japanese).

Hooke JM (1980) Magnitude and distribution of rates of river bank erosion. Earth Surface Processes and Landforms 5(2): 143-157.

Iwagaki Y (1956) Hydrodynamical study on critical tractive force. Proceedings of the Japan Society of Civil Engineers 41: 1-21 (in Japanese).

Iwasaki T, Shimizu Y and Kimura I (2012) Numerical simulation on bed evolution and channel migration in rivers. In Proceedings of River Flow 2012 (Murillo Munoz RE (ed.)). Taylor \& Francis, London, UK, pp. 673-679.

Jang CL and Shimizu Y (2005) Numerical simulation of relative wide, shallow channels with erodible banks.
Journal of Hydraulic Engineering ASCE 131(7): 565-575.

Julian JP and Torres R (2006) Hydraulic erosion of cohesive riverbanks. Geomorphology 76(1-2): 193-206.

Julien PY (2002) River Mechanics. Cambridge University Press, New York, NY, USA, pp. 88-94.

Laubel A, Kronvang B, Hald AB and Jensen C (2003) Hydromorphological and biological factors influencing sediment and phosphorus loss via bank erosion in small lowland rural stream in Denmark. Hydrological Processes 17(17): 3443-3463.

Lewin J (1976) Initiation of bed forms and meanders in coarse grained sediments. Geological Society of America Bulletin 87(2): 281-285.

Muir WD (2004) Geotechnical Modelling. Applied Geotechnics. Spon Press, London, UK, vol. 1, pp. 233-268.

Nagata N, Hosoda T and Muramoto Y (2000) Numerical analysis of river channel processes with bank erosion. Journal of Hydraulic Engineering ASCE 126(4): 243-252.

Nardi L, Rinaldi M and Solari L (2012) An experimental investigation on mass failures occurring in a riverbank composed of sandy gravel. Geomorphology 163-164(Special issue): 56-69.

Osman AM and Thorne CR (1988) Riverbank stability analysis. I: theory. Journal of Hydraulic Engineering ASCE 114(2): 134-150.

Peakall J, Ashworth PJ and Best JL (2007) Meander-bend evolution alluvial architecture, and the role of cohesion in sinuous river channel: a flume study. Journal of Sedimentary Research 77(3): 197-212.

Rinaldi M and Nardi L (2013) Modeling interactions between riverbank hydrology and mass failures. Journal of Hydraulic Engineering ASCE 18(10): 1231-1240.

Samadi A, Amiri-Tokaldany E, Davoudi MH and Darby SE (2011) Identifying the effects of parameter uncertainty on the reliability of modelling the stability of overhanging, multi-layered, river banks. Geomorphology 134(3-4): 483-498.

Samadi A, Amiri-Tokaldany E, Davoudi MH and Darby SE (2013) Experimental and numerical investigation of the stability of overhanging riverbanks. Geomorphology $\mathbf{1 8 4}$ : $1-19$.

Sturm TW (2001) Open Channel Hydraulic, 1st edn. McGraw-Hill, Singapore, pp. 100-102.

Sutarto T, Papanicolaou AN, Wilson CG and Langendoen EJ (2014) Stability analysis of semicohesive streambanks with CONCEPTS: coupling field and laboratory investigations to quantify the onset of fluvial erosion and mass failure. Journal of Hydraulic Engineering ASCE 140(9): 04014041-1-04014041-19, http://dx.doi.org/10.1061/ (ASCE)HY.1943-7900.0000899.

Taghavi M, Dovoudi MH, Amiri-Tokaldany E and Darby SE (2010) An analytical method to estimate failure plane angle and tension crack depth for use in riverbank stability analyses. Geomorphology 123(1-2): 74-83. 
Terzaghi K, Peck RB and Mesri G (1996) Soil Mechanics in Engineering Practice, 3rd edn. Wiley, New York, NY, USA. Thorne CR and Abt S (1993) Analysis of riverbank instability due to toe scour and lateral erosion. Earth Surface Processes and Landforms 18(9): 835-843.
Thorne CR and Tovey NK (1981) Stability of composite river banks. Earth Surface Processes and Landforms 6(5): 469-484.

Vanoni VA (1977) Sedimentation Engineering. ASCE, New York, NY, USA.
HOW CAN YOU CONTRIBUTE?

To discuss this paper, please email up to 500 words to the editor at journals@ice.org.uk. Your contribution will be forwarded to the author(s) for a reply and, if considered appropriate by the editorial board, it will be published as discussion in a future issue of the journal.

Proceedings journals rely entirely on contributions from the civil engineering profession (and allied disciplines). Information about how to submit your paper online is available at www.icevirtuallibrary.com/page/authors, where you will also find detailed author guidelines. 